\title{
DESIGN PARAMETERS FOR A SOUTH AFRICAN ICEBERG POWER AND WATER PROJECT
}

\author{
by \\ David J. DeMarle \\ (Rochester Institute of Technology, Rochester, NY 14623, U.S.A.)
}

\section{ABSTRACT}

Construction of an iceberg processing plant at Saldanha Bay, Republic of South Africa, is proposed. A reservoir would be constructed at Rieibaai for ice storage. Tidal forces would be harnessed to pump the warm water of Saldanha Lagoon over heat exchangers (using ammonia or propane gas as a heat exchange medium), thus providing power for electrical generators and for melting ice. A functional analysis of operations is presented, together with proposed costs. It is suggested that the fresh water and electricity produced by this system will cost $6 \xi / \mathrm{m}^{3}$ and $3 \phi / \mathrm{kwH}$, respectively.

\section{LIFE CYCLE STATUS OF ICEBERG UTILIZATION} PROPOSALS

In any scientific pursuit it is well to take stock of where you are. I think.it is appropriate to do this today, as we approach the close of this second meeting on the use of icebergs. If we know where we are, and where we have been, we can formulate better plans as to where we should be tomorrow.

Every project has a life cycle. In assessing the history of a large number of recent inventions, Bright (1972) found that a typical project went through several distinct phases in its development, illustrating this as a product life cycle (Fig. 1). In this life cycle, the average new product requires 18 years to develop from the initial suggestion to product status. Three of these years are spent in basic research, seven years in applied research, and seven years in product development. Where in this cycle does the use of icebergs as a fresh-water and power source stand? Weeks and Campbel1 (1969) presented the first scientific paper on this subject. The earlier suggestions of John Isaacs in the mid-1950s can be excluded because they were never published. During the eleven years that have elapsed since that paper, a great deal of attention has been given to the topic and much research has been done. Weeks and Campbell themselves published a more detailed article (1973). A review of the papers presented during the present conference, and at the 1977 conference (Husseiny 1978, Balaban 1979), suggests that we are still enmeshed in the initial stage of this project cycle. Perhaps this is to be expected, consider- ing how little we know about icebergs and the Antarctic and Arctic oceans and currents that both transport and degrade them.

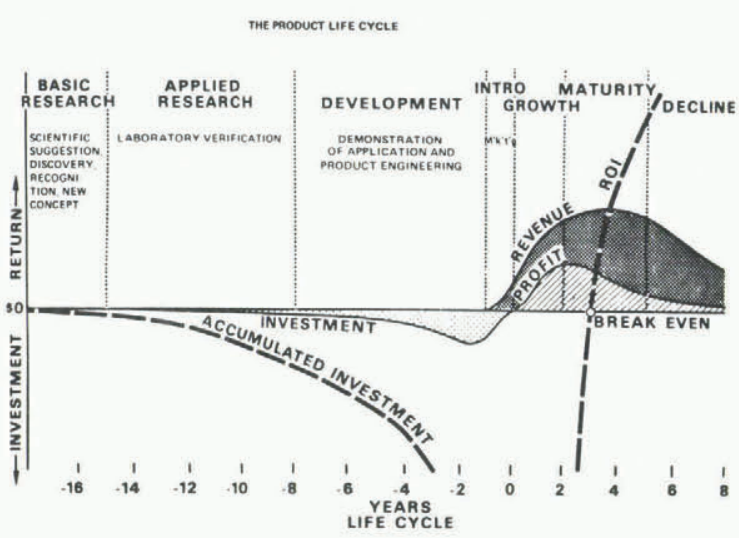

Fig.1. The product life cycle (after Bright).

Nonetheless, we live in a highly competitive technological age and it is important for us to turn from our basic research endeavors to the development of an engineering methodology that can bring water and power from this untapped natural resource to areas needful of these commodities. If this is not done quickly, I fear that the world may turn to technologies such as desalination to meet its future water needs. If the cost of desalination is lowered the incentive to fund the development of an iceberg technology will be lessened. Interesting as our expeditions and studies are, they are but the means to an end, and it is important for us to keep this end in mind as we continue to work in our respective avenues of research and development.

I have been involved in some conceptual studies of iceberg processing after towing to an appropriate delivery site. Some have pointed out the futility of these studies if it should prove impossible to tow icebergs to such sites. Superficially, such arguments seem valid, yet 
it is vital that we develop and maintain an economic approach to schemes for making use of icebergs. Studies of iceberg processing make sense since they have considerable impact on the cost of the end-product, and hence may act to control expenditure on transport systems. These economic constraints may prove to be more important than physical constraints on the success of an iceberg project. Even if it should prove impossible to transport icebergs, studies of shore-based water-storage locations will be necessary before ocean-based desalination plants can be developed. Finally, comprehensive studies of iceberg harvesting and processing are needed by government or private agencies who have to consider the merits of specific proposals for meeting future water and power needs. Adequate estimates of total costs and profits can be made only when an entire system is detailed. Lacking such an analysis, a potential client has to make a decision by intuition alone. Like the proverbial bird in the hand versus the bird in the bush, engineers will value water in a reservoir more than icebergs in an ocean.

\section{SOUTH AFRICAN ICEBERG UTILIZATION PROPOSAL}

It was with these thoughts in mind that I presented a paper (DeMarle 1979 [b]) on iceberg utilization at an international conference on value engineering that was held in Pretoria, South Africa, during October 1979. I proposed that Saldanha Bay, about $113 \mathrm{~km}$ north of Capetown, South Africa, would make an excellent site for an iceberg processing station, and while in South Africa, I consulted members of the Department of Water Affairs about this proposal. They arranged a visit to the Saldanha Bay area and other areas along the west coast of South Africa. I also visited a major irrigation project, as a guest of the Department of Agricultural Technical Affairs. Many people do not realize that South Africa has a limited supply of fresh water and that the South Africans have used most of the available water sources in a comprehensive program of water projects throughout their nation. In inter-basin water transport, water conservation, and water reuse, the South Africans are without peer in the international community. They are interested in all proposals which may help them to meet their future water needs.

In my paper, I described the transport of icebergs from the Weddell Sea area via the cold Benguela current to the west coast of South Africa. The continental shelf here is narrow, so it seems probable that large icebergs $(180 \mathrm{~m}$ draft) could be brought to within $13 \mathrm{~km}$ of Saldanha Bay. Here, cold water $\left(9\right.$ to $\left.10^{\circ} \mathrm{C}\right)$ upwelling occurs, which would benefit iceberg processing at this site since melting rates would be 1 ow and the ecological effects of iceberg storage would be less severe. As a community, the development of Saldanha Bay is recent, and the population of the area is low. There is an excellent ocean harbor which is now used for shipping iron ore from the center of South Africa to world markets. Located only $113 \mathrm{~km}$ from Capetown to the south, and $113 \mathrm{~km}$ from Clanwilliam (a major agricultural area under irrigation) to the north, the Bay is a logical site for storing water obtained from either an iceberg project or a desalination plant.
Offshore processing

Assuming that an iceberg has been grounded at a mooring location $15 \mathrm{~km}$ offshore at Saldanha Bay, processing would begin after the iceberg was moored on the continental shelf. Conventional drag-embedment anchors would be of transient use only, as they depend on long catenary holding lines at only a few degrees above the horizontal for their drag-holding capacity, so the iceberg would probably be moored to vertical resistance anchors permanently embedded in the ocean floor. These anchors would permit the use of shorter mooring cables and would provide better vertical holding ability than dragembedment anchors would. Explosive-embedment anchors with holding capacities from 5 to 50 tonnes have recently been developed by the U.S. Navy Civil Engineering Laboratory and could simplify iceberg mooring.

Factors such as tidal fluctuations, and ocean swe1ls and storms, would tend to lift the iceberg from its grounded position, and would probably require the use of multiple-point mooring systems. Processing operations aimed at altering the buoyancy of the iceberg in order to maintain contact with the sea-bed would be used to counter these ocean effects. Mooring systems, and the cables used for them, are discussed in more detail by Weeks and Mellor (1978).

Once the iceberg is grounded and moored, it could be enclosed by a plastic curtain. This curtain (suspended from a series of floats and appropriately weighted at the bottom)would be towed around the iceberg by a ship, and then fastened to provide a plastic enclosure. The curtain would insulate the iceberg by retarding the loss of melt water from the iceberg. Water that upwells along this coast at $10^{\circ} \mathrm{C}$ would result in a relatively low rate of heat transfer across the curtain and hence keep the melt rate of the iceberg at an acceptable level. An open curtain would probably not prevent pollution of fresh melt water by salt water. Studies by Huppert (1980) on ice melting indicate that such pollution should be expected, and hence, the main function of the plastic curtain would be to retard the melt rate of the iceberg.

Once the iceberg was enclosed by this floating curtain, mining operations would begin. Weeks and Mellor (1978) suggested how this could be done, and Smith (1978) discussed methods of fracturing ice by means of hydrostatic wedges. The iceberg could also be bench blasted around its edge; during the Norwegian Antarctic Research Expedition of 1978-79, such blasting yielded 3.5 tonnes of ice/kg explosive (Orheim 1980). This value is higher than the values reported by Weeks and Mellor (1978). South Africa's expertise in mining operations should be of real value in devising efficient, low cost methods for mining icebergs.

Using methods such as these, large slabs of ice would be broken from the iceberg surface and pushed into the sea around the berg. These slabs of ice would then be towed to shore in tugs. Alternatively, an ice slurry could be pumped to shore. Ice fragments floating on the sea surface would be collected and pumped to shore through a pipeline. This would eliminate the need for tug boats but would necessitate a permanent ocean pipeline station. As an iceberg was processed it would probably require mooring at a series of successive inshore 
positions. This would complicate the pipeline system, which would require complete enclosure to prevent salt water contamination of the iceberg. If this is too expensive, a system for separating and washing ice on shore would be needed.

Saldanha Bay reservoir and power plant

At Saldanha Bay, a part of the lagoon would serve as a storage area for ice harvested at the offshore processing station (Fig. 2). Saldanha Lagoon is a large body of shallow water to the south of Saldanha Bay. It is approximately $14 \mathrm{~km}$ by $3 \mathrm{~km}$, with a surface area of about $40 \mathrm{~km}^{2}$ at high tide. At low tide, numerous sand and mud flats are uncovered. Cold ocean water entering the lagoon as the tide. comes in is warmed by the sun to a temperature of approximately $20^{\circ} \mathrm{C}$. This represents a 10 deg differential and this heat, coupled with tidal pumping of the bay, offers a convenient heat source for power production and ice melting.

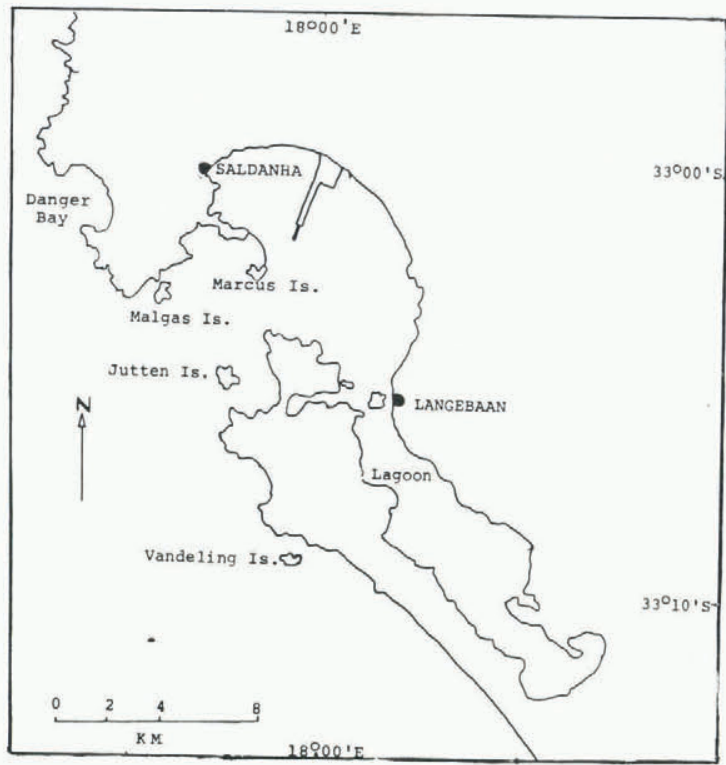

Fig.2. The Saldanha Bay area.

Rieibaai lies at the head of this lagoon opposite the town of Langebaan. This shallow bay is nearly $2 \mathrm{~km}$ long and is situated between two igneous intrusions. It would provide an excellent storage basin for ice that had been moved to the site from the offshore processing station (Fig. 3). The reservoir would be formed by constructing a $50-\mathrm{ft}[15 \mathrm{~m}]$ high sea wall, and would follow the $50-\mathrm{ft}[15 \mathrm{~m}]$ contour line on the topographical map. Access to the bay would be through a lock located at the entrance to Saldanha Lagoon, between Meeuw and Schapen islands. A power plant would be built between Rieibaai and Saldanha Lagoon which would use the lagoon as a heat source and Rieibaai as a heat sink. By selecting a gas such as ammonia or propane, a closed cycle would be set up where liquid gas would be vaporized in a heat exchanger located in the channel between Rieibaai and Schapen Island. The resulting gas would then be run through turbines to generate electricity, and would then be condensed to a liquid using ice in the Rieibaai reservoir. The cycle would be completed by pumping the liquid gas back into the heat exchanger in Saldanha Lagoon. This closed cycle would produce both melt water and electricity.

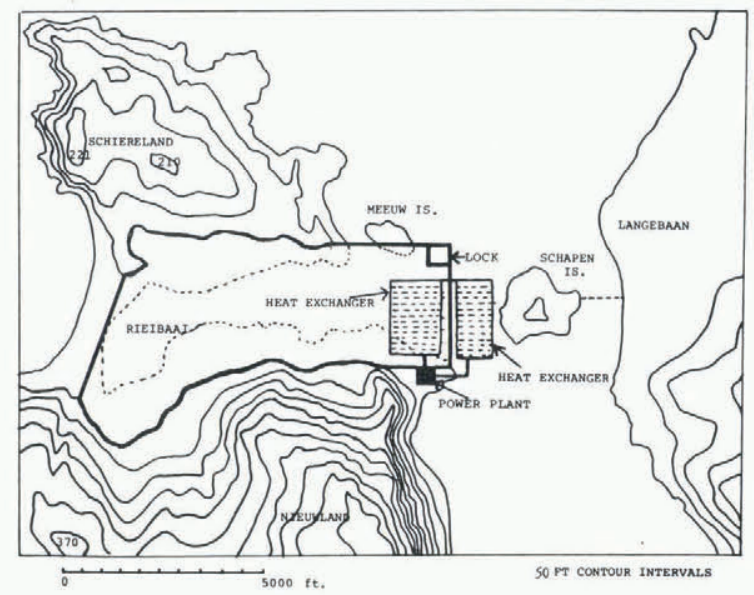

Fig.3. Schematic concept of iceberg reservoir and processing plant fashioned out of and built at Rieibaai.

A small tideway dam would be constructed between Schapen Island and Langebaan which would be used to control the tidal flow of water between Saldanha Bay and Lagoon. As the ocean tide rises this dam would be opened and would allow cold water to enter the lagoon. On the ebb of the tide, this dam would be closed and would force the warm lagoon water to flow out of the lagoon through the channel between Schapen Island and Rieibaai. A rapid current would improve heat transfer to the heat exchanger located in the channel. Accurate data on the mean tide level of the lagoon needs to be obtained together with the daily and seasonal characteristics of the tide. If we assume that the mean tidal range is $1 \mathrm{~m}$, and that the lagoon has an area of $4 \times 10^{7} \mathrm{~m}^{2}$, then a total of $4 \times 10^{7} \mathrm{~m}^{3}$ of water with an average $10 \mathrm{deg}$ temperature rise contains $1.5 \times 10^{15} \mathrm{~J}$. This massive daily quantity of heat would be available to generate power and melt ice at the power plant described above.

Dollar value of $i c e$ and power

Assuming that an iceberg $300 \mathrm{~m}$ by $900 \mathrm{~m}$ by $200 \mathrm{~m}$ thick remained after towing from an appropriate Antarctic location, this would yield $45900000 \mathrm{~m}^{3}$ of water worth $\$ 2754000$ at a cost of $6 \phi / \mathrm{m}^{3}$. With a latent heat of fusion of $3.332 \times 10^{5} \mathrm{Jkg}^{-1}$, the ice would have $1.532 \times 10^{6} \mathrm{~J}$ of cooling capacity. This represents a total power potential of $4.25 \times 10^{9} \mathrm{kWh}$. At $3 \phi / \mathrm{kWh}$, this represents a value of $\$ 127600000$. However, not all of this power would be available. If the power plant had an operating efficiency of $5 \%$, the ice could be used to produce $\$ 6,380,000$ worth of electricity. Power plants using ice were first described at the 1977 conference on the use of icebergs (Heizer 1978, Roberts 1978, DeMarle 1979(a)). 
The total value of the iceberg would thus break down as:

$$
\begin{aligned}
& \text { power at } 3 \phi / \mathrm{kWh} \quad \$ 6380000 \\
& \text { water at } 6 \$ / \mathrm{m}^{3} \quad \$ 2754000 \\
& \$ 9 \quad 134 \quad 000
\end{aligned}
$$

using South Africa's existing tugs.

\section{Functional target costs}

At the beginning of this paper it was stated that it is important for iceberg utilization to move on from the basic research phase into the development phase. Value engineering is an excellent methodology that can aid this process. This discipline uses functional descriptions and target costs to design systems to meet competitive costs. Figure 4 is a functional diagram that portrays the essential elements of a project for using icebergs. Functions to be accomplished are described in simple two-word phrases which are then interrelated by the how? and why? logic flow of the diagram. This type of diagram is described in more detail elsewhere (Bytheway 1971).

Subjective estimates were made for providing the functions on this diagram and have been entered as target costs. The total value in dollars of these costs accumulates as the subfunctions aggregate into the primary functions shown to the left of Figure 4 . The figures match those described above and would be replicated with each iceberg. Assuming that five icebergs per year were moved to this site and that the facilities would last twenty years, the total costs of these facilities are obtained by multiplying the one-time costs by 100 . It is my present belief that a practical and economical design for the Saldanha Bay location can be attained within the boundaries of these costs. When this design is completed, a major step towards the development of a low-cost method for using icebergs will have been achieved, and we can begin the hard work of developing a practical engineering system.

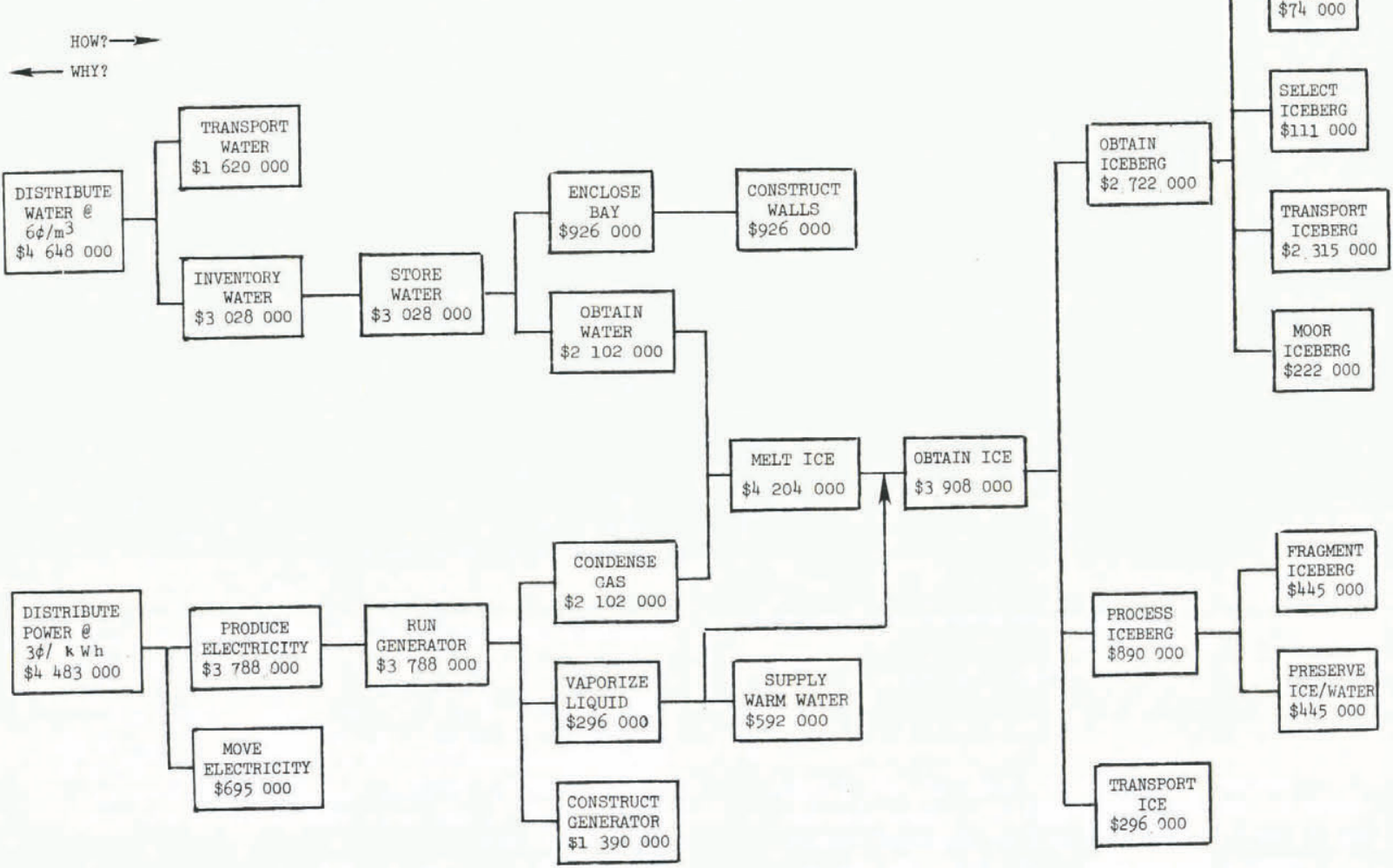

Fig.4. Functional diagram for power and water plant (with target cost per delivery for $5.4 \times 10^{7} \mathrm{~m}^{3}$ icebergs). 
REFERENCES

Balaban M (ed.) 1979 Comprising the second volume of the proceedings of the first International Conference on Iceberg Utilization, Ames, Iowa, 1977. Desalination 29 (1-2): 1-231

Bright J R 1972 A brief introduction to technology forecasting. Austin, Texas, Pemaquid Press

Bytheway C W 1971 The creative aspects of FAST diagramming. In Kaufman $\mathrm{J} \mathrm{J}$ (ed.) SAVE proceedings. Vol. 61971 national conference, Miami, Florida. Smyrna, Georgia, Society of American Value Engineers: $301-324$

DeMarle D J 1979 (a) Ice cooled ocean thermal energy conversion plants. Desalination $29(1-2): 153-163$

DeMarle D J 1979 (b) South African iceberg utilization: a proposal for fresh water production at Saldanha Bay. In Value in energy and conservation 1979. Proceedings of the intemational value engineering conference, Pretoria, South Africa, october 1979. Braamfontein, Value Engineering and Management Society of South Africa: 159-

Heizer R T 1978 Energy and fresh water production from icebergs. In Husseiny A A (ed.) Iceberg utilization. Proceedings of the first International Conference, Ames, Iowa, 1977. New York, Pergamon Press: $657-673$

Huppert H E 1980 The physical processes involved in the melting of icebergs. Annals of Glaciology 1: 97-101

Husseiny A A (ed.) 1978 Ieeberg utilization. Proceedings of the first Intermational Conference, Ames, Iowa, 1977. New York, Pergamon Press

Orheim 01980 Physical characteristics and life expectancy of tabular Antarctic icebergs. Annals of Glaciology 1:11-18

Roberts D M 1978 Icebergs as a heat sink for power generation. In Husseiny A A $(e d$. Iceberg utitization. Proceedings of the first Intemational conference, Ames, Iowa, 1977. New York, Pergamon Press: 674-688

Smith R A 1978 Iceberg cleaving and fracture mechanics - a preliminary study. In

Husseiny A A (ed.) Iceberg utilization. Proceedings of the first Intermational Conference, Ames, Iowa, 1977. New York, Pergamon Press: 176-190

Weeks W F, Campbel1 W J 1969 Icebergs as a freshwater source: an appraisal. International Association of Scientific Hydrology Publication 95 (Symposium on hydrology of glaciers): 255

Weeks W F, Campbe11 W J 1973 Icebergs as a fresh-water source: an appraisal. Journal of Glaciology 12(65): 207-233

Weeks W F, Mellor M 1978 Some elements of iceberg technology. In Husseiny A A $(e d$. Iceberg utilization. Proceedings of the first Intermational Conference, Ames, Iowa, 1977. New York, Pergamon Press: 45-98 